\title{
AN APPRAISAL OF THE EXCESS PROFITS TAX FROM A FISCAL STANDPOINT
}

\author{
Harold M. Groves*
}

Certain institutions though irreproachable as to ends are discredited by clumsy means; they are right and valid by definition but the definition will not stand the test of application. The excess profits tax belongs to this order.

We are committed for the war period to a program of high business taxation with much stress on the excess profits tax. It may be in order, nevertheless, to appraise the excess profits tax in the light of new experience. The degree of the tax, at least, is a matter for further consideration, and the question of what disposition to make of this emergency levy when peace is resumed is timely. To treat the latter issue satisfactorily it is necessary to raise anew the question of the proper place of business taxation and to weigh the excess profits tax against alternative sources of revenue.

\section{The Excess Profirs Tax as a War Measure}

The profits tax, as a war measure, stems from some sound roots in the soils of expediency and principle. It is not a matter of chance that this tax appeared in the war finance programs of most of the belligerent countries in the First World War and that it has been generally reintroduced during the present struggle. ${ }^{1}$

During both emergencies the excess profits tax has proved a mainstay of revenue yields for the United States. The excess profits tax of 1917 was described by Professor Robert Murray Haig" as "probably as deservedly unpopular as any tax measure could well be," and the later measures of the First World War left much to be desired. But these taxes brought money rolling into the Treasury, and they are now described as "the most important single source of tax revenue" during the war period. The record is still being made in the case of the present war, but it is already apparent that the excess profits tax will play a leading role as a revenue producer.

This war has set a high watermark for governmental control of the so-called private economy in the United States. Much of this control has taken the form of freezing pre-war economic relationships, including the prices of finished products, raw materials, and labor. The profits tax with its $90 \%$ rate and its emphasis upon

- Ph.D., University of Wisconsin. Professor of Public Finance, University of Wisconsin. Consultant to the United States Treasury Department on taxation problems. Formerly a member of the Wisconsin Tax Commission, and a member of both houses of the Wisconsin Legislature. Author of Financing GovernMeNT (I939). Contributor of articles on public finance and taxation.

${ }^{2}$ See Buehler, The Taxation of Corporate Excess Profits in Peace and War Times (1940) 7 Law \& Contemp. Prob. 291.

${ }^{3}$ Haig, The Revenue Act of 1918 (19r9) 34 PoL. Scr. Q. 382. 
pre-war experience of each individual company, aims at a near-freeze in the area of profits, not very different from that which is applied elsewhere in the economy.

An excess profits tax program, during this war, was nothing short of a political necessity. It was required to satisfy the demand of those who were involved at other points in the freezing process. It was an answer to those who sought insurance that none would profit from the nation's misfortune. It was demanded as a monetary counterpart to the sacrifice being made by persons who entered the armed forces. And it was a very plausible response to the feeling that the state has an equity in the profits created by its own extraordinary outlay.

The competitive checks upon excessive earnings normally operative (though not too perfectly) in times of peace are largely suspended during a war. This is due to the extraordinary rapidity of events and the extreme urgency of much of the demand. The Government becomes the sole buyer for many producers and in the sellers' market prevailing they can (except for the political controls) largely name their own prices.

If there are valid grounds of support for the excess profits tax in wartime, there are also many objections to it. One of the strongest is the legitimate doubt as to the sufficiency of the incentives remaining after the imposition of a very severe tax. The incentives to conserve and to risk and to produce at a maximum are hardly less and probably more important during war than normally. But a powerful new incentive is now available as a partial substitute for the profit motive. This is the patriotic incentive. It has elements of self-interest as well as of altruism. The former were stressed by Secretary Morgenthau when he stated before the Ways and Means Committee : "There can be no fair quarrel with the imposition upon corporations of a substantial proportion of the increased load of taxation required by our national peril. We are fighting for the very system of free enterprise which makes corporate profits possible." Businessmen have frequently expressed the conviction that they are not interested in abnormal profits during the war; that they intend to do their best for the war effort, profit or no profit. It would be naive, no doubt, to conclude that this attitude is universal, but it must be conceded that patriotism is an excellent lubricant for any tax mechanism in wartime.

Patriotism may be a good substitute for the incentives of free enterprise, but it cannot be as effective as a combination of patriotism and strong economic incentives. Some British critics have expressed the view" that "the economic incentives can be safely cut down to some extent (in war time) though it can not be cut down by more than a limited amount without dangerous consequences." This view is supported with the observation that "an excess profits tax is especially likely to fall upon the margin, where it will do most damage"s and "the opportunities for abuse and evasion inherent in an excessively high excess profits tax are enhanced by the fact that it is a temporary tax."

\footnotetext{
${ }^{3}$ Statement of Secretary of Treasury Henry Morgenthau, Hearings before the House Committee on Ways and Means, Revenue Revision of 1942, 77th Cong., 2d Sess. (1942) vol. I, p. 6.

${ }^{4}$ J. R. Hicks, U. K. Hicks, \& Rostas, The Taxation of War WeAlth (I94I) 44.

Id. at 43 .

'Id. at 45 .
} 
is done in the interests of future profits stands a good chance of evading the tax." And it is concluded that "a roo per cent tax, such as was imposed by the Italians in a weak moment in $19 x 9$, and such as is now in force in Great Britain, is beyond all question very dangerous indeed."

The quite substantial increase in advertising, despite the public interest in reduced consumption, both during the last war and this, can be cited in support of the fears expressed above. Much of this advertising is of the "goodwill" variety designed to enhance markets and hence profits after the war. This is done mainly at the expense of the Government (via reduced taxes) during the war. Probably advertising could be rationed. Also the Treasury might tighten its rules under which advertising outlays are deductible for tax purposes, but this would not be an easy solution from an administrative standpoint.

The nominal rate of $90 \%$ in the present federal law is somewhat softened by the overall limitation on federal corporate taxes (normal, surtax, and excess profits tax) at $80 \%$ of net income, and by the provision for a post-war credit to the extent of $10 \%$ of the excess profits tax. ${ }^{9}$ The exact degree to which an excess profits tax can be pushed without seriously undermining incentives is not determinable. The matter was carefully deliberated by the Treasury at the time the present excess profits tax rate was adopted, and, although Congress went considerably beyond the Treasury's recommendation in the rate finally chosen, the present levy may still be within the range of safety. It seems likely that the elasticity in this direction has at all events been exhausted.

The net effect of war profits taxation upon inflation is a question filled with complications and of doubtful answer. The problem offers at least four approaches. The first might be termed the pressure-on-prices approach. Insofar as producers can raise prices of their own volition, they may be discouraged by the excess profits tax, which requires in effect that price increases must be shared with the Government. On the other hand it may be argued that the excess profits tax has the exactly opposite effect, for producers will raise prices all the more in order to compensate for the levy. A second and probably more useful approach looks to the effect of the excess profits tax on purchasing power. Directly, the tax may cause a reduction of dividends, some of which would be destined for spending. But there are also indirect effects on purchasing power. The tax may lead to an "easy wage policy," that is, to reduced resistance to wage increases because of the producers' reduced stake in their marginal dollars. Here again the opposite can be argued but not very convincingly; that is, it can be contended that the tax increases wage resistance because it cuts down the surplus out of which such increases might be granted. The third approach is from the effect-on-cost angle. Does the tax lead to waste and carelessness, and are there loopholes like that for advertising expense which will be used to inflate costs and eventually prices? Finally, there is the political approach which considers the argument that heavy excess profits taxes are a condition precedent to asking labor to

${ }^{7}$ Ibid. ${ }^{8}$ Id. at 44.

- The Act allows the credit to be taken currently to the extent of $4 \%$ of the net debt repayments by the corporation during the taxable year. 
"take" wage controls and farmers to "take" price controls. Even this rather elaborate analysis does not exhaust the possibilities. Probably it is safe to conclude that the profits tax is not an effective check on inflation but that its net effect is at least not harmful.

Only a little less complicated and uncertain is the question of incidence of the excess profits tax. It is quite possible that government contracts, a very important element in industrial profits in wartime, are liberalized because of anticipated profits taxes. To the extent that this be true, these taxes involve only a circular movement of money out of and back to the Federal Treasury. They also fail in their objective of preventing unjust enrichment. The failure of quite heavy excess profits taxes to prevent much war-caused enrichment during the last war and the persistence of large net profits after taxes in this war lend plausibility to the theory. However, the plausibility decreases as the tax rate mounts. Obviously, if the rate were $100 \%$, any allowance for profits taxes in the terms of contracts would be futile. The much disputed renegotiation of contracts was based substantially on the thought that the incidence of an excess profits tax at less than confiscatory rates may be on the Government and may thus be ineffective in preventing excess profits. It has also been contended frequently ${ }^{10}$ that the incidence of the excess profits tax is partly on the consumer. Professor Seligman doubted the validity of this contention on the ground that there were probably untaxed marginal concerns even in wartime. ${ }^{11}$ Probably the strategic factors, such as the fact that price-determining forces operate in a sellers' market, are far more important than any considerations of marginality. The issue may seem to be of academic interest on the ground that the price-freezing program now probably prevents any important shifting to the consumer. Nevertheless there is no general agreement that the price controls are that effective.

It is quite well agreed that the weakest point in the armor of the excess profits tax is the technical difficulties of its application. No sensible person can be very enthusiastic about a tax measure which makes the ultimate rewards of the economic process mostly a matter of luck or of political (as contrasted with economic) efficiency. This is the danger that lurks in the technical difficulties of the excess profits tax. Undoubtedly the techniques of applying the tax have greatly improved since we last experimented with this form of taxation 25 years ago. But the arbitrariness and the anomalies are still very conspicuous. To choose a few more or less at random: Why should the concern that operates on borrowed capital have the privilege of including half of such capital in the tax base (for calculating the return on invested capital), whereas a firm which rents its capital has no such privilege? Why allow a personal service corporation to escape the excess profits tax on the ground that its income is mostly from services rather than capital, when many other corporations show the same characteristic but only to a lesser degree? Why tax a developing corporation on the theory that its success must be due to the war, while a declining corporation, which may have received a real lift because of the war, escapes? These matters are

\footnotetext{
${ }^{10}$ Seidman, Influence of Excess Profits Taxation on Business Policy in Financing the War (Tax Institute, 1942) 5 I.

${ }^{12}$ Seligman, Essays in Taxation (Ioth ed. 1925) 706.
} 
of course in addition to the standard complaint that no attention is given to varying degrees of risk. Relief provisions, the carry-over and carry-back of unused excess profits credit, and other refinements have helped make the present tax less arbitrary than those employed during the last war, but the staunchest friend of the tax would not claim that the technical problems of application are anywhere near solution.

Anyone who takes the pains to study the multitudinous points of subtle distinction and classification ${ }^{12}$ involved in an excess profits tax cannot fail to appreciate the very great possibilities for injustice and unfair competition that are involved in its application. An exceedingly complicated law is essential to cover the many conditions to which it must apply and much has to be left, even then, to administrative procedure. The historical approach to the definition of capital is probably the best that could be devised, but it involves resurrecting and some recasting of a multitude of records which have been regarded as buried. In this connection it may be recalled that when the excess profits tax came before Congress in the early years of the present war, there were cases still pending in the courts dealing with the determination of invested capital under the IgI8 law. ${ }^{13}$ Moreover, accounting is not an exact science, and it is hard put to give the precise answers required by a 90\% excess profits tax. Confronted with the prospects of unjust application in many instances, the lawmakers very generously gave the taxpayers a choice of alternatives-the invested-capital and the previous-earnings methods of calculating excess profits. But it is apparent that this combination of generosity and stringency will often not average out to a salutary result.

\section{Excess Profits Tax in the Transition Perjod and in Peacetime}

The excess profits tax is set up as an emergency measure and in such manner as to indicate the absence of an intent to carry it beyond the war and perhaps the interlude between war and peace. Even before the war is won, near-certainty of victory may weaken considerably the patriotic motive which helps sustain a very high rate of tax. A further trend in this direction during the post-war interlude should justify a downward revision of rates.

As we pass from conditions of war to those of peace, there will undoubtedly be a demand as there was in the 'twenties for a retention of the excess profits tax in the peacetime tax system. It is not too early to give some thought to whether we should accede to this demand. Most of the valid grounds for an excess profits tax in time of war disappear in time of peace, and most of the limitations of this form of taxation are accentuated. Most important of all is the fact that we have no conceptual basis for an excess profits tax in normal times. ${ }^{14}$ Most plausible of the suggested bases is that excess profitability results from monopolistic production and that we should try to measure and recapture the monopoly gains. There has been considerable sup-

${ }^{13}$ Shoup, The Taxation of Excess Profits (1940) 55 Pox. Scr. Q. 535, (194I) 56 id. 84, 226; Seidman, Exchange Provisions of the Excess Profits Tax (194I) 19 Taxes 75.

${ }^{13}$ Statement of Colin F. Stam, Joint Hearings before the House Committee on Ways and Means and the Senate Committee on Finance, 76th Cong., 3d Sess. (1940) 104.

26 Of course, the comparison of present profits with those of a selected period of prior years would have to be abandoned. The relation of income to invested capital would necessarily be the basis of a permanent tax. 
port for the view that income should be differentiated qualitatively as well as quantitatively for taxation. But if there were any clear way to isolate monopoly profits, it would probably be possible to prevent them from occurring in the first place. We do know that in an order of perfect competition, profits would differ among concerns due to a difference in the risk factor. In some lines of business most of the companies might make substantial profits all of the time while in other lines, profits would fluctuate from year to year and from concern to concern, depending upon the degree of success in the assumption of risks. No doubt there are unnecessary rewards in this picture, but no plausible technique for singling them out has yet been devised.

There are many ways to attack the monopoly problem. One is old-fashioned trustbusting; another is public regulation of selected prices; a third is public ownership; a fourth is joint public-private corporations in certain areas; and a fifth is the cooperative movement, which has had some success as a counter-monopoly program in Sweden. On top of these is the excess profits tax, a recapture program. This monopoly problem is clearly no easy nut to crack, and none of these approaches to a solution should be lightly abandoned. But the excess profits tax seems to be among the least promising.

The anti-monopoly movement, a very strong current in several eras of American history and still a vital force, might seek to check the concentration of economic power in several more specific ways. It might seek to limit: (I) the size of personal incomes; (2) the size of business units; and (3) the rate of business profits. Much can be said for the first of these objectives, particularly if it is attempted through progressive taxation and without any fixed arbitrary limit. Even the notion that there should be some upper limit to the size of the "catch" one can make in the economic stream, while a departure from tradition, can be defended in the name of many democratic values. As to the second objective, some businesses are undoubtedly larger than the social interest warrants; but it seems improbable that we know enough to restrict the size of business without doing more harm than good. And the last objective seems least promising of all. To limit the rate of profit is, in effect, to make preferred stock out of common stock. Undoubtedly the limited dividend corporation has its place as a voluntary institution. But to eliminate or largely eliminate by legislation the venture factor in business, seems quite inadvisable. The time may come when its preservation will be unnecessary but that state of abundance has not yet arrived.

There was much concern during the 'thirties over the weakness of the urge to invest and the failure of investment to revive substantially after the intense depression of the early years of the decade. Many suggestions were made for changing the tax system so as to make it more conducive to investment. No one ever proposed the excess profits tax for that purpose. To be sure it could be argued that such a program would rest lightly upon infant industries. But this would not weigh heavily against the discouragement to investment resulting from profits-tax penalties upon efficiency and successful risk-taking.

It has many times been observed that the social interest in less inequality of income may run counter to that in the encouragement of private investment. But the two interests may not be entirely in conflict. Taxes which are levied closest to the 
operation of business and particularly those that are applied at the margin of operation are probably especially inimical to the incentives which are important to conserve. Taxes which are applied to the distribution of the end product are probably less repressive and they are also far more certain in their effect on inequalities. They would be even more certain if it were not for the inapplicability of personal taxes to the undistributed income of corporations.

\section{The Role of Business Taxes in the Tax System}

This leads to a consideration of the proper future role of business taxes in the tax system.

In the author's view there is very little gained by the imposition of heavy taxes on business. In the last analysis all taxes, including those levied on business, have to be paid by persons. The special benefits that business as such is supposed to receive are wrapped in obscurity as to their distribution, and it may well be that they are really general benefits enjoyed by all who have an occupation or any other source of livelihood. To be sure, these taxes serve the opportunistic end of filling the Treasury. But the ultimate incidence of these levies is quite obscure. Even the retail sales tax, the last resort of most public finance writers, is much less obscure than most business taxes in its incidence.

There are those who dislike the personal income tax because it is so well adapted for use in altering the distribution of income after taxes. To others this is the principal virtue of the tax. But to still others the income tax offers the supremely important virtue that it taps the income stream directly and offers a minimum of confusion as to incidence.

To those who would welcome greater emphasis on personal net income taxation, the problem of undistributed business income is a formidable impediment. It is plausibly argued that we must have the heavy emphasis upon business taxation as long as a very significant part of the economic product and the acquisition of economic power is detoured around the field to which personal taxation is confined. It will be recalled that $T$. S. Adams, after the last war, suggested that an undistributed profits tax be substituted for the excess profits tax. We experimented with a special $\operatorname{tax}$ on undistributed income in the late 'thirties with rather unhappy results. But the circumstances were so unpropitious and the instrument adopted was so crude that the experience can hardly be judged conclusive. Business itself might be well-advised to trade the excess profits tax and much of the present corporate net income tax for a well-framed undistributed income tax.

\section{Conclusion}

The war excess profits tax, while open to valid objection, is probably warranted as an emergency measure; it has probably been pushed to the limit of safety in its present application; it will become less acceptable and should be mitigated when it can no longer be sustained by patriotism; its elimination should be attended by a revision of the whole business tax system, in which business taxes should be de-emphasized and a well-designed program to apply personal taxes to undistributed business income should be inaugurated. 